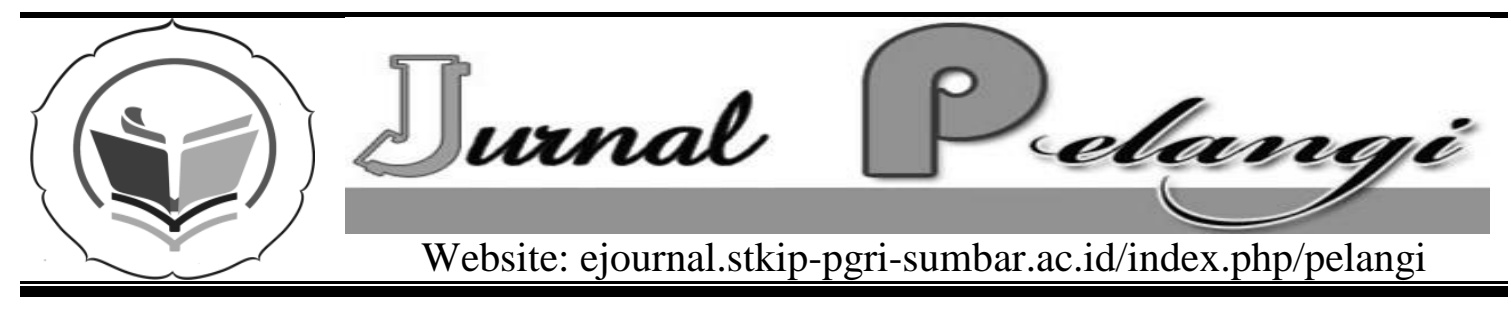

\title{
PENINGKATAN HASIL BELAJAR PENDIDIKAN KEWARGANEGARAAN MENGGUNAKAN RANCANGAN PEMBELAJARAN QUANTUM TEACHING
}

\section{Ratnawati}

SD Negeri 12 Kampung Melayu Kecamatan Ampek Nagari Kab. Agam ratnawati200@gmail.com

\section{INFO ARTIKEL}

Diterima:

1 Desember 2015

Direview:

15 Desember 2015

Disetujui:

22 Desember 2015

Kata Kunci:

Hasil belajar PKn, Quantum Teaching
Keywords:

Civic Education

Learning Outcome,

Quantum Teaching

\begin{abstract}
Abstrak
Penelitian dilatar belakangi dari kenyataan di Sekolah Dasar bahwa pembelajaran sering didominasi oleh guru sebagai sumber informasi Berdasarkan pengamatan peneliti ditemukan hasil belajar siswa rendah. Disini peneliti menggunakan komponen Jenis penelitian ini adalah Penelitian Tindakan Kelas (PTK). Penelitian ini menggunakan pendekatan kualitatif dan kuantitatif. Penelitian ini adalah PTK (Penelitian Tindakan Kelas) yang terdiri dari II siklus 2 kali pertemuan dengan empat komponen yaitu perencanaan, tindakan, pengamatan dan refleksi. Sumber data adalah proses pelaksanaan pembelajaran dengan komponen. Hasil penelitian menunjukan siklus I bahwa dari penilaian RPP diperoleh skor nilai 71, dari aspek guru diperoleh skor 63,5, dari aspek siswa diperoleh skor 50, hasil belajar siswa diperoleh nilsi kognitif adalah 67, nilai afektifnya 56, sedangkan nilai psikomotornya adalah 59. Sedangkan pada siklus II dari penilaian RPP diperoleh skor nilai 93, dari aspek guru diperoleh skor 83, dari aspek siswa diperoleh skor 79, hasil belajar siswa diperoleh nilsi kognitif adalah 81, nilai afektifnya 89, sedangkan nilai psikomotornya adalah 76, terlihat bahwa hasil belajar siswa meningkat dari siklus I ke siklus II. Dengan demikian terungkap bahwa penggunaan komponen
\end{abstract}


Classroom Action Research (CAR). It used quantitative and qualitative. It consisted of two cycles and 2 meetings through the four components, i.e. planning, acting, observing and reflecting. The source of the data was the implementing process in learning through the components of of learning design of quantum teaching at students $V$ class Elementary School 12 Kampung Melayu Kecamatan Ampek Nagari, Agam Regency. The research subjects were all of the $V$ class students, i.e. 11 students. The research results show that in first cycle, the lesson plan (RPP) shows the score 71, teacher scores is 63,50, the students aspect is 50. The students learning outcome has a cognitive score, i.e. 67, the affective is 56, the psychomotoric is 59. Meanwhile, in the second cycle, the lesson plan shows the score 93, teacher score is 83, the student's aspects is 79. The students learning outcome has a cognitive score, i.e. 81, the affective score is 89, and the psychomotoric score is 76 . It can be seen that from first cycle to second cycle, the student's learning outcome improves. So that, the learning outcome of Civic Education by using the components of learning design of quantum teaching improves the student's learning outcomes at students V Class of Elementary School 12 Kampung Melayu Kecamatan Ampek Nagari, Agam Regency.

\section{PENDAHULUAN}

Proses pembelajaran merupakan proses yang mengandung serangkaian perbuatan guru dan siswa atas dasar hubungan timbal balik yang berlangsung dalam situasi edukatif untuk mencapai tujuan tertentu. Interaksi atau hubungan timbal balik antara guru dan siswa merupakan syarat utama bagi berlangsung proses pembelajaran. Mata pelajaran Pendidikan Kewarganegaraan (PKn) merupakan salah satu mata pelajaran yang diajarkan di Sekolah Dasar (SD).Salah satu metode pembelajaran yang dapat dipakai dalam pembelajaran PKn yaitu Metode Pembelajaran Quantum Teaching. Metode pembelajaran ini dimulai dari presentase guru tentang tujuan materi pembelajaran, menumbuhkan atau mengembangkan minat siswa untuk belajar, menciptakan atau mendatangkan pengalaman umum yang dapat dimengerti oleh semua pelajar, menyediakan kata kunci, konsep, metode, rumus, dan strategi sebagai masukan, memberikan peluang pada siswa untuk menerjemahkan dan menerapkan pengetahuan ke dalam kehidupanya, memperkuat koneksi syaraf dan menumbuhkan rasa tahu atau yakin terhadap kemampuannya, dan memberikan umpan balik pada siswa atas keberhasilanya, baik berupa pujian, maupun pemberian hadiah.

$$
\text { Menurut Bobbi (2009: }
$$
pembelajaran Quantum Teachingadalah "penggubahan belajar yang ilmiah dengan semua nuansanya, yang menyertakan segala kaitan, interaksi dan perbedaan yang memaksimalkan momen belajar serta berfokus pada hubungan dinamis dalam lingkungan kelasinteraksi yang mendirikan landasan dalam kerangka untuk belajar". 


\section{METODE PENELITIAN}

Penelitian ini adalah Penelitian Tindakan Kelas (PTK) dengan menggunakan komponen-komponen rancangan pembelajaran Quantum teaching pada siswa kelas V SD Negeri 12 Kampung Melayu Kecamatan Ampek Nagari Kabupaten Agam. Data yang diperoleh dalam penelitian dianalisis dengan menggunakan model analisis data kualitatif. Analisis data kualitatif yakni analisis data dimulai dengan menelaah sejak pengumpulan data sampai seluruh data terkumpul. Data tersebut direduksi berdasarkan masalah yang diteliti, diikuti penyajian data dan terakhir penyimpulan atau verifikasi.

\section{HASIL DAN PEMBAHASAN}

Pembahasan hasil penelitian siklus I meliputi perencanaan pembelajaran, pelaksanaan pembelajaran dan penilaian hasil belajar dengan menggunakan metode Quantum Teaching.

\section{Perencanaan}

Perencanaan pembalajaran yang disusun sesuai dengan komponenkomponen, yaitu Kompetensi Dasar (KD) yang merupakan pernyataan yang mewujudkan perilaku yang harus dapat dilaksanakan siswa setelah pembelajaran berlangsung. Menurut Depdiknas (2006) Kompetensi Dasar berisikan pernyataan umum tentang kompetensi yang seharusnya dikuasai, sebab pernyataan ini bersifat umum maka masih sulit diukur keberhasilannya. Rumusan kompetensi dasar disusun berdasarkan tujuan dalam kurikulum, kebutuhan belajar dan karakteristik siswa.
Untuk memperkecil ruang lingkup dari kompetensi dasar maka dirumuskan indikator dengan kata-kata operasional yang jelas. Indikator ditulis dalam bentuk kata kerja yang merupakan tindakan belajar dalam pencapaian kompetensi dasar.Untuk lebih mempertajam lagi indikator ini dispesialisasikan lagi dengan membuat tujuan pembelajaran. Tujuan pembelajaran ditulis dengan lengkap dan mencakup aspen $\mathrm{ABCD}$ ( $\mathrm{A}=$ audience, $\mathrm{B}=$ behavior, $\mathrm{C}=$ conditioan, $\mathrm{D}=$ degree) tujuan pembelajaran yang dibuat sesuai dengan materi pembelajaran.

Materi ajar yang dipilih sesuai dengan tujuan pembelajaran, sesuai dengan karakteristik siswa, sesuai dengan bahan yang diajarkan dan sesuai dengan kebutuhan siswa.Cakupan materinya harus luas, diajarkan sesuai dengan alokasi waktu yang ditentukan dan sesuai dengan perkembangan terakhir bidangnya. Materi yang diajarkan menggunakan metode Quantum Teaching sesuai pula dengan media yang dipakai. Menurut Sutarto (2005:39) pemilihan media disesuaikan dengan tujuan pembelajaran, karakteristik siswa dan lingkungan siswa untuk mendukung keberhasilan proses pembelajaran, jadi penggunaan media juga sangat penting dalam pembelajaran PKn.

Pada perencanaan pembelajaaran berikutnya adalah menentukan langkahlangkah pembelajaran secara urut, mulai dari kegiatan awal, inti dan akhir. Teknik pembelajarannya disesuaikan dengan langkah-langkah metode Quantum Teaching yaitu: Tumbuhkan minat dengan memuaskan, alami, namai, 
demonstrasikan, ulangi dan rayakan. Instrumen penilaian sesuai dengan prosedur, tujuan pembelajaran, dilengkapi dengan soal dan kunci jawaban serta penskoran yang lengkap.Berdasarkan hasil penilaian observer terhadap RPP pada siklus I diperoleh skor rata-rata 71 dengan kategori cukup.

\section{Pelaksanaan}

Pembelajaran dilaksanakan oleh peneliti sebagai guru, dan teman sejawat sebagai observer, guna mengamati jalannya pembelajaran mulai dari awal sampai akhir pembelajaran, baik dari aspek guru maupun aspek siswa. Sugiyanto (2009:73-78) adalah sebagai berikut: (1) Pembelajaran kuantum berpangkal pada psikologi kognitif, bukan fisika kuantum, (2) Pembelajaran kuantum lebih bersifat humanistik, (3) Pembelajaran kuantum lebih bersifat kontruktivis, (4) Pembelajaran kuantum lebih memusatkan perhatian pada interaksi yang bermutu dan bermakna, bukan sekedar transaksi makna, (5) Pembelajaran kuantum sangat menekankan pada pemercepatan pembelajaran dengan taraf keberhasilan tinggi, (6) Pembelajaran kuantum sangat menekankan kealamihaan dan kewajaran proses pembelajaran, bukan keadaan yang dibuat-buat, (7) Pembelajaran kuantum sangat menekankan kebermaknaan dan kebermutuan proses pembelajaran, (8) Pembelajaran kuantum memiliki model yang memadukan konteks dan isi pembelajaran, (9) Pembelajaran kuantum memusatkan perhatian pada pembentukan perhatian pada pembentukan keterampilan akademis, dan prestasi,

Pembelajaran kuantum menempatkan nilai dan keyakinan sebagai bagian penting proses pembelajaran, (11) Pembelajaran kuantum mengutamakan keberagaman dan kebebasan, bukan keseragaman dan ketertiban, (12) Pembelajaran kuantum menginteraksikan totalitas tubuh dan pikiran dalam proses pembelajaran.

Pembelajaran dilaksanakan sesuai dengan perencanaan pembelajaranyang telah dijelaskan diatas, serta mengikuti komponen-komponen rancangan pembelajaran Quantum Teaching. Berdasarkan pengamatan observer, penyebab siswa kurang memahami pelajaran disebabkan oleh beberapa hal, yaitu pembelajaran yang masih membingungkan bagi siswa, disebabkan kurangnya petunjuk atau arahan yang diberikan guru.Masih didominasi oleh siswa yang pintar dan aktif. Kurangnya kemampuan siswa dalam proses pembelajaran. Hal ini berdasarkan pengamatan observer terhadap pembelajaran yang telah dilakukan pada siklus I keberhasilan dari aspek guru diperoleh skor 62.5 dengan kriteria cukup, dari aspek siswa diperoleh skor 50 dengan kriteria kurang. Jadi berdasarkan data yang didapat dapat disimpulkan bahwa pembelajaran PKn dengan menggunakan komponrnkomponren rancangan pembelajaran Quantum Teaching belum berhasil dengan baik, dan akan dilanjutkan dan diperbaiki pada siklus II.

Hasil belajar siswa dapat dilihat dari kemampuan siswa dalam mengingat pelajaran yang telah disampaikan guru selama proses pembelajaran dan 
bagaimana siswa tersebut dapat menerapkannya dan mampu memecahkan masalah yang timbul sesuai dengan apa yang sedang dipelajari siswa tersebut. Hal ini sesuai dengan pendapat Purwarto (1996:18) yang menyatakan bahwa " hasil belajar siswa dapat ditinjau dari beberapa hasil kognitif yaitu kemampuan siswa dalam pengetahuan (ingatan), pemahaman, penerapan (aplikasi), analisis, sintesis, dan evaluasi". Hasil belajar dapat dilihat dari segi tiga aspek yakni kognitif, pemahaman dan aplikasinya.Selain itu menurut Sudjana (1990:2) menegaskan "Hasil belajar siswa pada hakekatnya adalah perubahan tingkah laku pada aspek kognitif, afektif, dan psikomotor".

Dari hasil penelitian siklus I dapat diketahui persentase nilai kognitif adalah 68, nilai afaktif 56 dan psikomotor 59. Berdasarkan hasil pengamatan siklus I yang diperoleh maka direncanakan untuk melanjutkan ke siklus II. Pada kegiatan pembelajaran siklus II diharapkan guru lebih memperhatikan langkah-langkah pembelajaran yang akan dilaksanakan agar dapat menerapkan didalam kelas dengan baik, sehingga hasil belajar yang diinginkan tercapai.

Pembahasan hasil penelitian siklus II meliputi perencanaan pembelajaran, pelaksanaan pembelajaran dan penilaian hasil belajar dengan menggunakan metode Quantum Teaching.

\section{Perencanaan}

Perencanaan pembalajaran yang disusun sesuai dengan komponenkomponen, yaitu Kompetensi Dasar (KD) merupakan pernyataan yang mewujudkan perilaku yang harus dapat dilaksanakan siswa setelah pembelajaran berlangsung. Menurut Depdiknas (2006) Kompetensi Dasar berisikan pernyataan umum tentang kompetensi yang seharusnya dikuasai, sebab pernyataan ini bersifat umum maka masih sulit diukur keberhasilannya Untuk memperkecil ruang lingkup dari kompetensi dasar maka dirumuskan indikator yang disusun secara spesifik dan menggunakan kata-kata operasional yang jelas. Indikator ditulis dalam bentuk kata kerja yang merupakan tindak belajar dalam pencapaian kompetensi dasar. Untuk mempertajam lagi indikator ini dispesifikasikan lagi dengan membuat tujuan pembelajaran. Tujuan pembelajaran ditulis dengan lengkap dan mencakup aspek ABCD ( $\mathrm{A}=$ Audience, $\mathrm{B}=$ Behavior, $\mathrm{C}=$ Conditioan, $\mathrm{D}=$ Degree).

Materi ajar yang dipilih sesuai dengan tujuan pembelajaran, sesuai dengan karakteristik siswa, sesuai dengan bahan yang diajarkan dan sesuai dengan kebutuhan siswa.Cakupan materinya harus luas, diajarkan sesuai dengan alokasi waktu yang ditentukan dan sesuai dengan perkembangan terakhir bidangnya.Materi yang diajarkan menggunakan metode Quantum Teaching sesuai pula dengan media yang dipakai. Menurut Sutarto (2005:39) pemilihan media disesuaikan dengan tujuan pembelajaran, karakteristik siswa dan lingkungan siswa untuk mendukung keberhasilan proses pembelajaran, jadi penggunaan media juga sangat penting dalam pembelajaran PKn.

Pada perencanaan pembelajaaran berikutnya adalah menentukan langkah- 
langkah pembelajaran secara urut, mulai dari kegiatan awal, kegiatan inti dan kegiatan akhir. Teknik pembelajarannya disesuaikan dengan langkah-langkah metode Quantum Teaching yaitu: Tumbuhkan minat dengan memuaskan, alami, namai, demonstrasikan, ulangi dan rayakan. Instrumen penilaian sesuai dengan prosedur, tujuan pembelajaran, dilengkapi dengan soal dan kunci jawaban serta penskoran yang lengkap.Berdasarkan hasil penilaian observer terhadap RPP pada siklus II diperoleh skor rata-rata 93 dengan kategori baik.

\section{Pelaksanaan}

Pembelajaran dilaksanakan oleh peneliti sebagai guru, dan teman sejawat sebagai observer, guna mengamati jalannya pembelajaran mulai dari awal sampai akhir pembelajaran, baik dari aspek guru maupun aspek siswa. Sugiyanto (2009:73-78) adalah sebagai berikut: (1) Pembelajaran kuantum berpangkal pada psikologi kognitif, bukan fisika kuantum, (2) Pembelajaran kuantum lebih bersifat humanistik, (3) Pembelajaran kuantum lebih bersifat kontruktivis, (4) Pembelajaran kuantum lebih memusatkan perhatian pada interaksi yang bermutu dan bermakna, bukan sekedar transaksi makna, (5) Pembelajaran kuantum sangat menekankan pada pemercepatan pembelajaran dengan taraf keberhasilan tinggi, (6) Pembelajaran kuantum sangat menekankan kealamihaan dan kewajaran proses pembelajaran, bukan keadaan yang dibuat-buat, (7) Pembelajaran kuantum sangat menekankan kebermaknaan dan kebermutuan proses pembelajaran, (8) Pembelajaran kuantum memiliki model yang memadukan konteks dan isi pembelajaran, (9) Pembelajaran kuantum memusatkan perhatian pada pembentukan perhatian pada pembentukan keterampilan akademis, dan prestasi, Pembelajaran kuantum menempatkan nilai dan keyakinan sebagai bagian penting proses pembelajaran, (11) Pembelajaran kuantum mengutamakan keberagaman dan kebebasan, bukan keseragaman dan ketertiban, (12) Pembelajaran kuantum menginteraksikan totalitas tubuh dan pikiran dalam proses pembelajaran.

Hal ini berdasarkan pengamatan observer terhadap pembelajaran yang telah dilakukan pada siklus II keberhasilan dari aspek guru diperoleh skor 83 dengan kriteria baik, dari aspek siswa diperoleh skor 79 dengan kriteria cukup. Pembelajaran dilaksanakan sesuai dengan perencanaan pembelajaran yang telah dijelaskan diatas, serta mengikuti langkah-langkah komponenkomponen rancangan pembelajaran Quantum Teaching. Berdasarkan pengamatan observer, pelaksanaan pembelajaran siklus II sudah menuju kearah yang lebih baik. Sebab pelaksanaanya sudah sesuai dengan langkah-langkah pembelajaran.

Hasil belajar siswa dapat dilihat dari kemampuan siswa dalam mengingat pelajaran yang telah disampaikan guru selama proses pembelajaran dan bagaimana siswa tersebut dapat menerapkannya dan mampu memecahkan masalah yang timbul sesuai dengan apa yang sedang dipelajari siswa tersebut. Hal ini sesuai dengan 
pendapat Purwarto (1996:18) yang menyatakan bahwa "hasil belajar siswa dapat ditinjau dari beberapa hasil kognitif yaitu kemampuan siswa dalam pengetahuan (ingatan), pemahaman, penerapan (aplikasi), analisis, sintesis, dan evaluasi". Hasil belajar dapat dilihat dari segi tiga aspek yakni kognitif, pemahaman dan aplikasinya.Selain itu menurut Sudjana (1990:2) menegaskan "Hasil belajar siswa pada hakekatnya adalah perubahan tingkah laku pada aspek kognitif, afektif, dan psikomotor".

Dari hasil penelitian siklus II dapat diketahui persentase nilai kognitif adalah 81, nilai afaktif 89 dan psikomotor 76 . Berdasarkan hasil pengamatan siklus II yang diperoleh maka pelaksanaan siklus II dinyatakan sudah berhasil. Dimana guru sudah berhasil meningkatkan hasil belajar siswa sesuai dengan yang diharapkan.

\section{PENUTUP}

Berdasarkan pembahasan yang telah dilakukan, dapat diambil kesimpulan bahwa dengan mengguna-kan metode Quantum Teaching dapat meningkatkan hasil belajar siswa pada pembelajaran PKn.

Berdasarkan data hasil penelitian dan pembahasan tentang upaya peningkatan pembelajaran PKn dengan menggunakan metode Quantum Teaching dapat disimpulkan sebagai berikut:

1. Perencanaan pembelajaran PKn dengan menggunakan komponenkomponen rancangan pemelajaran Quantum Teaching dilaksanakan dengan menggunakan tiga tahap pembelajaran, yaitu kegiatan awal, kegiatan inti, dan kegiatan akhir. Selain itu juga menyiapkan media yang sesuai dengan materi agar siswa dapat termotivasi ketika belajar. Pada perencanaan pembelajaran ini observer memberi skor penilaian siklus I skornya 71 , siklus II skornya 93.

2. Pelaksanaan pembelajaran dengan menggunakan komponen-komponen rancangan pembelajaran Quantum Teaching dilaksanakan mengikuti perencanaan yang telah dilakukan sesuai dengan komponen-komponen rancangan pembelajaran Quantum Teaching. Pengamatan dilakukan oleh guru kelas yang bersangkutan dengan mengisi rambu-rambu pengamatan baik untuk aspek guru dan aspek siswa sehingga apabila terjadi kesalahan dan kekurangan akan terlihat pada lembaran tersebut. Dimana skor dari masing-masingnya dilihat dari aspek guru siklus I adalah 62,5, siklus II adalah 83 . Pada aspek siswa siklus I adalah 50, siklus II adalah 79.

3. Hasil belajar PKn dengan menggunakan komponen-komponen rancangan pemelajaran Quantum Teaching pada siswa kelas V SD Negeri 12 Kampung Melayu sudah meningkat. Dari hasil penelitian siklus I dapat diketahui skor nilai kognitif adalah 68, skor nilai afektif adalah 56 dan skor nilai psikomotor adalah 59. Siklus II dapat diketahui skor nilai kognitif adalah 81, skor nilai afektif adalah 89 dan skor nilai psikomotor adalah 76 .

Berdasarkan simpulan di atas, disarankan hal-hal sebagai berikut: 
1. Pembelajaran PKn dengan menggunakan metode Quantum Teaching layak dipertimbangkan oleh guru untuk menjadi pembelajaran alternatif yang dapat digunakan sebagai referensi dalam memilih metode pembelajaran.

2. Bagi guru-guru yang ingin menerapkan pembelajaran dengan menggunakan metode Quantum Teaching, agar lebih kreatif dalam merancang pembelajaran yang sesuai dengan situasi dunianya dan perlu memberikan perhatian, bimbingan dan motivasi belajar secara sungguh-sungguh kepada siswa yang berkemampuan kurang dan pasif dalam kelompok, karena siswa yang demikian sering mengantungkan diri pada temannya.

\section{UCAPAN TERIMA KASIH}

Terbitnya tulisan ini tidak terlepas dari bantuan berbagai pihak, untuk itu penulis ucapkan terima kasih yang sebesar-basarnya kepada Pihak STKIP PGRI Sumatera Barat khususnya pengelola jurnal Pelangi yang telah memberikan kesempatan kepada penulis untuk menulis dijurnal Pelangi. Selanjutnya penulis juga berterima kasih kepada para penyumbang sumber inspirasi yang telah memberikan inspirasi bagi penulis untuk mengutip atau menggunakan tulisannya sebagai bahan referensi.

\section{DAFTAR PUSTAKA}

A.T. Rusyan. 2005. Meningkatkan Mutu dalam Proses Pembelajaran Pendidikan Pancasila dan Kewarganegaraan. Jakarta: Universitas Terbuka

Bobbi Deporter. 2011. Quantum Teaching. Bandung: Kaifa Mizan Pustaka.

Depdiknas. 2006. Kurikulum Tingkat Satuan Pendidikan. Jakarta: Badan Standar Nasional Pendidikan 2006. UU RI No. 14 Th. 2005 tentang Guru dan Dosen serta UURI No. 20 Th 2003 tentang Sisdiknas. Citra Umbara: Bandung

Oemar Hamalik. 2008. Metodik Belajar dan Kesulitan Belajar. Bandung: Ganesha

Purwanto dkk. 1996. Metodologi Pengajaran Bahasa Indonesia Di Sekolah dasar. Bandung : Rosda.

Sudjana. 1990. CBSA, Proses Belajar Mengajar. Bandung : Sinar baru. Bangi: Fakulti Pendidikan UKM.

Suyatno. 2009. Metode-Metode Pembelajaran Inovatif. Surakarta: Panitia Sertifikasi Guru. 